\section{The reliability of the Albustix test for proteinuria}

M. R. WILLS and G. K. MCGOWAN From the Department of Clinical Pathology, United Bristol Hospitals

Albustix (Ames Co.) provide a quick and simple test for proteinuria. These test papers are impregnated with tetrabromophenol blue and a citrate buffer of $p \mathrm{H} 3$; the indicator is yellow at this $p \mathrm{H}$ but changes to blue over the $p \mathrm{H}$ range $3 \cdot 0-4 \cdot 6$. In the presence of protein the property of the indicator is changed (the so-called 'protein error') in such a way that it is blue at $p \mathrm{H} \mathrm{3}$. A change of colour to blue therefore constitutes a positive reaction; it will be given not only by protein but also by urines which are alkaline enough to shift the $p \mathrm{H}$ of the buffer above about 4 , and by conditions which leach out the buffer, such as leaving the paper immersed in urine for more than about one second or holding it in a stream of urine. Conversely, a urine which has been strongly acidified may give a false negative result.

In general the test has been found reliable provided that the urine has not become stale and alkaline, and although 'trace' false positives have been reported on many fresh urines these may well be due to mucus(Baron and Newman 1958; Frazer, 1958; Macgregor, 1958). In our laboratory the Albustix test has been compared with the boiling test after acidification to $p \mathrm{H} 5.4$ on 1,345 urines. Only three gave a false positive with Albustix; all were at least one day old and strongly alkaline, and after adjustment to $p \mathrm{H} 6$ all became negative.

We have, however, received from Dr. J. E. Cates two urines giving false positive Albustix tests which are not due to alkalinity. The first was positive $(+++)$ to Albustix at the original $p \mathrm{H}$ of 5.8 and remained positive after adjustment to $\mathrm{pH} 3$; it was negative by the sulphosalicylic acid, trichloroacetic acid, and boiling tests. Because of the known 'salt error' of indicators the electrolyte content was investigated but was not found to be unduly high (sodium $15 \mathrm{mEq} / \mathrm{l}$., potassium $40 \mathrm{mEq} / \mathrm{l}$., phosphate 51

Received for publication 19 February 1963 mg./100 ml.). Some nitrogenous constituents other than protein were estimated and found to be within the normal range (non-protein nitrogen $2,055 \mathrm{mg} . / 100 \mathrm{ml}$., creatinine $105 \mathrm{mg}$. $/ 100 \mathrm{ml}$., amino-acids $17 \mathrm{mg} . / 100 \mathrm{ml}$. rising to 31 $\mathrm{mg} . / 100 \mathrm{ml}$. after hydrolysis). As the non-protein nitrogen was in the upper part of the normal range and presumably consisted mainly of urea, the effect of adding $4 \mathrm{~g}$. of urea to $100 \mathrm{ml}$. of normal urine was tested; the urine remained negative to Albustix.

The second urine was positive $(+)$ to Albustix at the original $p \mathrm{H}$ of 8 , and remained positive after correction to $p \mathrm{H} 5$ and also to $p \mathrm{H} \mathrm{3.} \mathrm{It} \mathrm{was} \mathrm{negative} \mathrm{to} \mathrm{the} \mathrm{sulpho-}$ salicylic acid, trichloroacetic acid, and boiling tests. Nitrogenous compounds were non-protein nitrogen $720 \mathrm{mg} . / 100 \mathrm{ml}$., creatinine $117 \mathrm{mg} . / 100 . \mathrm{ml}$., and urate $68 \mathrm{mg} . / 100 \mathrm{ml}$., and the amino-acid chromatogram was normal. Electrolytes were sodium $230 \mathrm{mEq}$./1., potassium $72 \mathrm{mEq}$./1., chloride $174 \mathrm{mEq}$./1., calcium $21 \mathrm{mg}$. $/ 100 \mathrm{ml}$., and phosphate $72 \mathrm{mg} . / 100 \mathrm{ml}$. A centrifuged deposit was normal and culture was sterile. As the sodium and chloride concentrations were rather high, the effect of adding $2 \mathbf{g}$. of salt to $100 \mathrm{ml}$. of urine was tested (i.e., addition of 340 $\mathrm{mEq} . / 1$.$) ; the urine remained negative to Albustix.$

\section{CONCLUSIONS}

It is rare for Albustix to give more than a 'trace' false positive reaction with fresh urines, and it is probable that these are usually due to mucus which has not settled.

Strong false positives may be given by strongly alkaline urines, but these can be avoided if every urine is first tested for alkalinity and made just acid to litmus when necessary.

Very occasional false positives ${ }^{1}$ occur $(+$ to +++$)$ which are not due to alkalinity. In the two examples recorded here the cause was not found, but it does not appear to be the 'salt error' of indicators, nor the presence of a very high urea concentration.

\section{REFERENCES}

Baron, D. N., and Newman, F. (1958). Brit. med. J., 1, 980. Frazer, S. C. (1958). Ibid., 1, 981. Macgregor, A. G. (1958). Ibid., 2, 430.

${ }^{1}$ Hall (Brit. med. J., 1961, 2, 1566) has pointed out that false positives are given by certain detergents in high dilution. Our urine samples were collected in hospital containers which are cleaned with a detergent which does not react with Albustix. 